\title{
Policy instruments and welfare state reform
}

Article

Accepted Version

Jensen, C., Arndt, C., Lee, S. and Wenzelburger, G. (2018) Policy instruments and welfare state reform. Journal of European Social Policy, 28 (2). pp. 161-176. ISSN 1461-7269 doi: https://doi.org/10.1177/0958928717711974 Available at https://centaur.reading.ac.uk/72609/

It is advisable to refer to the publisher's version if you intend to cite from the work. See Guidance on citing.

Published version at: http://journals.sagepub.com/doi/abs/10.1177/0958928717711974

To link to this article DOI: http://dx.doi.org/10.1177/0958928717711974

Publisher: Sage

All outputs in CentAUR are protected by Intellectual Property Rights law, including copyright law. Copyright and IPR is retained by the creators or other copyright holders. Terms and conditions for use of this material are defined in the End User Agreement.

\section{www.reading.ac.uk/centaur}

\section{CentAUR}

Central Archive at the University of Reading

Reading's research outputs online 


\title{
Policy instruments and welfare state reform
}

\author{
Carsten Jensen \\ Christoph Arndt \\ Seonghui Lee \\ Georg Wenzelburger
}

Accepted for publication in

Journal of European Social Policy 


\begin{abstract}
A core, but so far untested, proposition of the new politics perspective, originally introduced by Paul Pierson, is that welfare state cutbacks will be implemented using so-called 'invisible' policy instruments, e.g. a change in indexation rules. Expansion should, by implication, mainly happen using 'visible' policy instruments, e.g. a change in nominal benefits. We have coded 1,030 legislative reforms of old-age pensions and unemployment protection in Britain, Denmark, Finland, and Germany from 1974 to 2014. With this unique data at hand, we find substantial support for this crucial new politics proposition.
\end{abstract}

\title{
Keywords
}

Welfare reforms; blame avoidance; credit claiming; new politics of the welfare state 


\section{Introduction}

Reforming the welfare state is not easy. It can be electorally dangerous for the politicians willing to try because voters will oppose cuts in their entitlements. Big, visible reforms such as a cut in nominal benefits are, as a result, rare - and if they occur, voters will punish the responsible politicians by voting for another party. If reforms happen, they will therefore most of time be 'invisible', e.g. a technical change in indexation rules or the assessment base for calculating benefits. In a nutshell, this is the core claim of Pierson's $(1994 ; 1996)$ classic argument about the new politics of the welfare state.

The new politics perspective has spurred one of the most fruitful debates in the welfare state literature. Clayton and Pontusson (1998), Korpi and Palme (2003) and Allan and Scruggs (2004) were quick to point out that the welfare state, and especially benefits to the jobless, has been retrenched quite a bit; an observation that has been repeated several times since (e.g. Clasen, 2007; Clasen and Clegg, 2011; Jensen, 2014). The basic claim that retrenchment is unpopular has also been questioned: Giger (2010; 2011), Giger and Nelson (2013) and Schumacher et al. (2013), among others, show that there is no, or only a very conditional, association between cuts in replacement rates and the subsequent vote share of governments.

It would appear, in short, that the new politics argument has been firmly refuted. Governments can more or less do what they want without fear of an electoral backlash. We have no quarrels with this critique of the new politics argument; it would seem that there have been many cutbacks and that governments, on average, have escaped blame. Yet one central proposition of the new politics argument has never been put to the test: namely whether cutbacks are implemented using certain 'invisible' policy instruments. To be sure, both Pierson himself and later research (e.g. Lindbom, 2001; 2007; Zohlnhöfer, 2007; Jensen, 2011; Wenzelburger, 2011; Green-Pedersen et al., 2012) showed that politicians 
sometimes use such blame avoidance tactics in concrete reform situations, but we have no systematic information about what the balance is between 'visible' and 'invisible' policy instruments more broadly in welfare state reforms.

This deficit is a serious one. If it is true, as Pierson originally argued, that cuts will typically come in the form of 'invisible' policy instruments, this can explain both why retrenchment has been possible and why this has not systematically led to an electoral backlash. This is because voters should be less able to associate politicians and parties with policy changes the voters dislike. In contrast, if 'visible' policy instruments are the name of the game when the welfare state is retrenched, this would be one more blow to the new politics argument.

To move the debate forward, we have collected data on all pension and unemployment reforms in Britain, Denmark, Finland, and Germany from 1974 to 2014 and coded which policy instruments were actually employed. This means that we cover countries with very different welfare models (Esping-Andersen, 1990; Korpi and Palme, 1998) across two policy fields that enjoy diverse levels of public support (van Oorschot, 2006). In total, we have coded 1,030 policy instruments using a coding scheme with 13 distinct categories that cover all major aspects of citizens' social rights, including benefit qualification period, nominal benefit level, indexation rules and employability requirements. This gives us a unique opportunity to explore which policy instruments are used, for what purpose (expansion or cutbacks) and in which countries.

We find a relatively consistent picture. Nominal benefits levels, arguably the most 'visible' policy instrument there is, are much more frequently changed when social rights are being expanded than when they are being cut. This is particularly the case when it comes to highly popular old-age pensions, whereas cuts to nominal benefits are comparably more frequent in unemployment benefits. There is also a clear tendency for 'invisible' policy 
instruments to be more frequently used in the context of cutbacks, and more so for pensions than for unemployment.

We also find interesting cross-country variation. The starkest pattern of 'visibility' being associated with expansions and 'invisibility' with cutbacks is found in Britain and Denmark. Two explanations are plausible for this result. First, in Germany and Finland welfare benefits are often insurance-based, which means that issues relating to, for instance, contribution levels and the assessment base for calculation of benefits are more important - as a result of how the programs are set up technically. Second, the political systems of Germany and Finland exhibit what Powell and Whitten (1993) call low clarity of responsibility especially due to the frequent use of coalition governments. However, if voters do not know whom to blame for a welfare cutback, the probability for a government to be punished or at the ballot box is much lower. Consequently, the pressure on governments to hide cuts by choosing invisible instruments decreases in countries where the institutional setup of the political system blurs responsibility attribution. This may be another reason why German and Finnish politicians might have opted for a broader selection of policy instruments: they simply had less to fear from the voters than their peers in Britain and Denmark. This, in sum, is also an example of how the choice of policy instrument is dependent on the national context.

\section{Instrument choice and the new politics of the welfare state}

A prerequisite for voters to punish politicians for retrenching welfare is that the voters are able to link events such as a declining living standard to concrete policy choices and, ultimately, individual politicians or parties. Without such a 'causal chain of responsibility', voters cannot react to changes they dislike (Arnold, 1990). According to Pierson (1994: 20), this means that ' $[t]$ hose engaged in efforts to initiate unpopular policies will try to lower 
visibility of their reforms by complicating the reconstruction of causal chains that would allow voters to exact retribution'.

There are several ways to achieve such causal blurring, but the most straightforward is by selecting policy instruments that by design make it difficult for voters to evaluate the negative effect of a reform (Pierson, 1994; see also Weaver, 1986). A given welfare program normally consists of a number of elements, all of which can be changed as part of a reform. The most fundamental, of course, is the benefit paid out to recipients. A benefit recipient will, if she pays any attention, notice that the monthly benefit has been reduced. This is not just because the nominal benefit is what defines a welfare program, but also because it is easy to understand and has immediate consequences in terms of declining living standards.

There are, however, many other elements that in combination make up a welfare program. First, there are the rules governing access. These can include waiting periods (how long after a social risk occurs before a person is eligible?) and contribution levels and periods (how much and for how long must a person contribute to a program before she is eligible?). Second, there are rules governing benefit generosity. The most obvious is nominal benefit level, as discussed above, but there are also duration (for how long can a recipient receive benefits?), indexation rules (is the nominal benefit automatically regulated to correct for rising inflation or wages and with what factor?), and assessment base (in earnings-related programs, what part of the wage sum is used to calculate benefits, and how precisely is it done?). Third and finally, there are rules governing the behaviour of benefit recipients. The most important of these are rules regarding employability (e.g. is the recipient required to or offered the opportunity to voluntarily participate in activities meant to increase the likelihood of getting a job?). 
Many of these elements are much more technical, and therefore more difficult to comprehend, than changes in nominal benefit levels. Changing indexation has been highlighted as a prime example of so-called 'invisible' cutbacks (Pierson, 1994: 20-21, 173; Lindbom, 2007: 137-138; Green-Pedersen et al., 2012). If benefits are made to increase at a slightly lower rate than previously, this will escape the notice of most people, partly because nominal benefits will stay the same as before (and perhaps even increase, though at a slower rate) and partly because the effect will only manifest itself over the course of years. Benefits that are indexed at a lower rate than inflation will, over time, entail a substantial decrease in the purchasing power and, hence, living standards of recipients. Altering the wage base for calculating benefits may be even more opaque to voters. Other rules such as qualification and contribution periods are also likely to go unnoticed by most ordinary citizens.

The assumption of Pierson and other adherents of the new politics perspective is that modern-day welfare state politics is about avoiding blame for unpopular decisions. Yet while it is certainly true that the period since the 1970s has seen many cuts to citizens' entitlements, it is not the case that expansion has been off the table either. Indeed, a little more than half of the policy instruments we coded for Britain, Denmark, Finland and Germany related to the expansion of citizens' social rights. The majority of the expansions were in old-age pensions, but even for unemployment protection a sizable minority of all recorded changes were expansions (for more details, see below).

[Figure 1 and 2 about here]

Whether a policy instrument entails an expansion or reduction in generosity does not, of course, tell us anything about the magnitude or importance of the change. To gauge the relative importance of expansionary and retrenching events, we can consult the Generosity 
Index for unemployment benefits and old-age pensions from the Comparative Welfare Entitlements dataset. The Generosity Index is a composite measure based on information on replacement rates (calculated as the percentage of the wage of the average production worker that an unemployed person or retiree is entitled to), rules governing access, and overall coverage of the citizenry (for details, see Scruggs, 2014). While not perfect, and certainly not exhaustive, the Generosity Index nevertheless provides an indication of the realized, or de facto, social rights that citizens in a country on average enjoy.

Figure 1 graphs generosity for the retired in Britain, Denmark, Finland, and Germany from 1974 until 2010. With the exception of Germany, overall generosity has barely budged at all. Figure 2 turns to unemployment protection (where there is data until 2011 for three countries). Here the marked drops, not least in the first part of the Thatcher years, emerge clearly in the British time series. Denmark saw declining generosity in the 1990s and again as a reaction to the Great Recession, while German generosity dropped most substantially after the Hartz reforms in the 2000s. That said, generosity levels have hardly collapsed.

The point we want to make is not that no cutbacks have occurred - they have in great numbers. Indeed, according to our data, since 1974 the four countries have experienced 492 cutbacks in total, 316 of which were in unemployment protection programs. The point we want to make is rather that instances of expansion have not disappeared: they have occurred 534 times, to be exact. On balance, these expansionary events have kept generosity levels roughly the same for the old, while the smaller number of expansions compared to cutbacks in unemployment programs have meant a sliding generosity level for the jobless.

In the terminology of Weaver (1986) and Pierson (1994), the fact to appreciate is that there have been many more credit-claiming opportunities than is normally assumed in the literature. Politics is not all about avoiding blame for unpopular decisions. It is - still - 
also about being rewarded for making policies that voters like. In the context of choosing politically appropriate policy instruments, this is not trivial. If 'invisible' policy instruments should be the preferred mode of implementing cuts, 'visible' policy instruments should be the preferred mode for expansions. This way, politicians should be best positioned to reap electoral rewards for pleasing voters.

Adding an extra layer of complexity, the institutional design of welfare programs is likely to have a big impact on the choice of policy instruments as well (EspingAndersen, 1990; Pierson, 1993; 1994; Korpi and Palme, 2003). ${ }^{1}$ In tax financed universalist schemes based on citizenship rights like in Denmark, changes to nominal benefit levels, indexation rules or age brackets should be much more common, given that these parameters decide who gets how much benefits for how long. ${ }^{2}$ In contrast, governments in charge of an insurance-based system, such as the German system, have a much more diverse choice of policy instruments which can be used to adjust the welfare state. Given the importance of the insurance-mechanism, they will probably change the parameters of the formulae on the basis of which benefits are calculated, which involves policy instruments such as the contribution period, the assessment base as well as indexation rules. In contrast, a direct lowering of nominal benefit levels is less probable, given that they are perceived as individual 'rights' based on paid contributions. Finally, means-test is an important feature of the liberal welfare state, which is why this policy instrument should play an important role when existing

\footnotetext{
${ }^{1}$ We do not discuss changes in private and occupational systems here. Although their development may be related to changes in public schemes (Wolf et al. 2014), the decisions are usually outside the direct responsibility of the governments which is why strategic use of instruments is not to be expected.

${ }^{2}$ It may be argued that nominal benefits are so low in Denmark that cutting them is unrealistic in an otherwise generous welfare state. Yet, although Danish first tier pension coverage is relatively low, it is worth noting that there is a means-tested component that doubles the nominal benefits for single and increases it with $50 \%$ for couples. The means-tested benefit only caps off with an income of around 42,000 euros for singles and 49,000 for couples. More importantly, and as we also show in Table 3, nominal benefits are rarely cut, but other elements of the pensions are instead. Almost a third of all cuts consist of increasing the age bracket, which does not affect the living standard of the retirees (i.e. creates additional poverty). In other words, there are ways for Danish politicians to cuts old age pensions without creating additional poverty - and this appears to be the way that cuts frequently have occurred.
} 
programs are implemented. Besides our clear cases - Denmark representing the Nordic welfare state, Germany the conservative insurance-based system, and UK the liberal welfare state - Finland qualifies as a hybrid between the welfare state of Denmark, where benefits are traditionally earned as a matter of citizenship rights, and that of Germany, where benefits are mostly earned via contribution payments (for details on the Finnish case, see Kangas, 2007; Kangas and Saari, 2007; for broader cross-country comparisons emphasizing the same point, see Scruggs and Allan, 2006; Castles and Obinger, 2008).

In sum, citizenship-based welfare programs will tend to see action on a smaller number of policy instruments than insurance-based welfare programs. None of the four countries we survey have purely citizenship- or insurance-based old-age pension or unemployment protection systems, as probably no country does. Still, Britain and Denmark certainly come closer to the citizenship-based end of the spectrum and Germany closer to the insurance-based end, with Finland in between. We therefore expect to see the most diverse choice of policy instruments in the latter two.

The political system's institutional design should also matter because it affects the so-called clarity of responsibility (Powell and Whitten, 1993; Pierson, 1994). If responsibility for political decisions is easy to place with the government, it is also easier for voters to blame the government for unpopular decisions (or credit it for popular ones). Clarity of responsibility can be blurred either by institutional features of the political system itself such as strong second chambers with veto powers or a Presidential system. Or it can be affected by the type of government with clear responsibility attribution in the case of singleparty majority governments and a more blurred attribution in the case of coalitions. In fact, Hobolt et al. (2013) show that the institutional setup matters much less than the cohesion of 
the government for performance voting - and, consequently, for the incentives of governments to use strategic timing in order to escape such performance voting. ${ }^{3}$

Among our four countries, Britain exhibits the highest government clarity because of its tradition of single-party government, absence of cohabitation, and comparable ideological cohesion of the government. Both Finland and Germany have a tradition of multiparty governments, sometimes ideologically very diverse, that blurs responsibility significantly. Denmark has multiparty minority governments, but a party system where parties are grouped into two clearly demarked blocs. In sum - and in line with the government clarity-scores calculated by Hobolt et al. (2013) - we expect to see the strongest pattern of strategic use of policy instruments in Britain, followed by Denmark, Germany and Finland.

Because the key contention of the new politics perspective is that politicians want to avoid being blamed for unpopular decisions and, if possible, receive credit for making popular ones, the overall popularity of different welfare programs should matter. Plenty of research documents that support for programs aimed at the able-bodied, above all else unemployment protection, is much less popular than programs aimed at the sick and the old (van Oorschot, 2006; Jensen and Petersen, 2016). This is mainly due to the character of risks the respective programs address (Jensen 2012). Whereas pensions cover the life-cycle risk of old age and everybody expects to benefit from a pension when he or she gets old, unemployment protection is directed at labour-market risks and, clearly, not all citizens have the same hazard to get unemployed. A natural expectation from this observation is that the most marked use of 'invisible' policy instruments will be in relation to cuts in welfare programs like old-age pensions, elderly care and health. Similarly, when it comes to

\footnotetext{
${ }^{3}$ More exactly, Hobolt et al. (2013) defines institutional clarity by weak committees, unicameralism, absence of federalism, and a parliamentary system. Government clarity, on the other hand, is defined by dominance of one party, single-party government, absence of cohabitation, and ideological cohesion of the government.
} 
expansionary reforms, the most marked use of 'visible' policy instruments should also be in relation to these popular welfare programs.

\section{The data}

Our dataset contains information on legislative changes in the social rights of citizens with regard to old-age pensions and unemployment protection in Britain, Denmark, Finland, and Germany from 1974 to 2014 . The two programs were selected for three reasons. First, they constitute a core part of what is conventionally understood as 'the welfare state' and, as a result, are prominently featured in a very long list of publications on the politics of the welfare state. Second, old-age pensions are normally much more popular than unemployment protection among the public, as explained above. Third, both programs are transfer schemes, meaning that we can code them using the same coding scheme, which is important if we want to compare the two programs.

As already indicated, the four countries were chosen because they provide great variation in terms of their respective welfare state models (Esping-Andersen, 1990; Korpi and Palme, 1998; Scruggs and Allan, 2006; Castles and Obinger, 2008) and political systems (Lijphart, 1999). Britain and Denmark share an emphasis on citizenship as the basis for eligibility, but apart from that are very different. Britain is a classic example of a residual welfare state, where benefits are mostly means-tested and relatively low. Denmark, in comparison, has substantially more generous benefits and less frequently employs a (strict) means test. Germany is the archetypal insurance-based system, where benefits are tied to earnings history and membership of occupational schemes. Finland is frequently lumped together with the other Nordic countries, but in fact exhibits several insurance-based features both when it comes to unemployment protection and old-age pensions (Kangas, 2007). The 
four countries also represent different political systems and therefore have different degrees of clarity of responsibility.

The time period was chosen because 1974 marks the first full year after the first oil price crisis. It is conventional to view 1973 as the end year of the Golden Age of welfare state expansion as well as the signalling of the new era of permanent austerity (Pierson, 1994; 1996). It is in this period where we should expect to find the clearest attempts at blame avoidance from re-election-motivated politicians and therefore also the period we believe is relevant to document empirically.

For the dataset we coded all legislative changes relating to the 13 aspects of citizens' social rights, listed in Table 1, with numbers 1-6 reflecting rules of access, numbers 7-10 reflecting rules of generosity, and numbers 11-13 reflecting rules of recipient conduct. For each of the 13 dimensions we identified whether the reform event implied a cutback or an expansion in citizens' social rights. For example, in 1995 the British government reduced the maximum duration of the unemployment insurance benefit from one year to six months. This is coded as a cutback in the duration period (no. 7 on the list above). The same year the British government increased the pension age of women from 60 to 65 years. This is coded as a cutback in the social rights relating to age brackets (no. 5 on the list). Employability is coded as an expansion if a recipient is offered the option to participate in an activity and as a cutback if participation is mandatory.

[Table 1 about here]

Deciding what policy instruments are 'visible' and 'invisible' is not hard science, but must ultimately rest on an arbitrary assessment. Degree of visibility may, moreover, also vary by country because some elements are simply more important in some places. This is an issue 
we return to below. The end points, at least, are relatively easy to pin down. Changes in nominal benefits level (no. 8) and age brackets (no. 5) are clearly 'visible', while indexation (no. 9) and assessment base (no. 10) are 'invisible'. We would also argue that duration period (no. 7), employability (no. 11), and means testing (no. 6) are quite 'visible', though less so than nominal benefits level. Qualification (no. 1) and contribution periods (no. 2) are, conversely, technical and unlikely to attract the attention of most citizens, so we consider them relatively 'invisible'. The remaining policy instruments are considered in-between.

To gather information about reforms, we collected as many secondary sources as possible and supplemented these with searches in legislative databases when necessary. The coding was conducted by a team of trained research assistants and all coding decisions were subsequently controlled by a senior researcher. In the event the senior researcher did not agree with the original coding, the relevant research assistant and senior researcher discussed the coding decision in detail to reach agreement; however, there were very few such instances.

To illustrate the data structure, Figure 3 displays the coded expansionary and retrenching changes in British unemployment protection since 1974. The black circles with a full line connecting them represent expansions, whereas the hollow circles with a dashed line represent cutbacks. On the vertical axis the number of coded changes is listed. The major reforms in 1980, 1986, 1995, and 2011/12 are clearly visible. It is also obvious that there have been many more cutbacks than expansions in the area of unemployment protection. This is in line with extant research, which often highlights the British experience as outstanding for the retrenchment it has witnessed (e.g., Allan and Scruggs, 2004; Clasen, 2007; Clasen and Clegg, 2011; Jensen, 2014). It is also worth noting that while the Generosity Index in Figure 2 reported essential stability in the domain of British unemployment benefits after the 
first wave of cutbacks in the 1980s, our data pick up the major reforms we know to have happened. We believe, in other words, that our data has a high degree of face validity.

\section{Policy instrument choice in four countries}

Table 2 presents the data for Britain. The policy instruments are organized with the most 'visible' at the top and the most 'invisible' at the bottom. The first two columns report the data for old-age pensions and the last two columns the data for unemployment protection. The numbers are within-column percentages. In the first column, for instance, we see that 54.8 per cent of all pension expansions are in nominal benefit level, while the remaining 45.2 per cent is spread out over the other 12 policy instruments. In the second-to-last row, the number of observations is reported, and in the last row, the ratio between expansions and cutbacks is reported. This gives an impression of whether the policy area has seen more expansions than cuts.

Table 2 is revealing. Starting at the bottom, we first observe that pensions have seen more expansions than cutbacks, while the opposite is true for unemployment protection. With regard to how the expansions and cutbacks were implemented, we see the expected pattern. Nominal benefits where changed more than three times as often when pensions were expanded compared to when they were retrenched. Age brackets, another 'visible' policy instrument, were admittedly changed in relation to cutbacks (i.e. raising the retirement age), but even when considering nominal benefit level and age brackets together, 'visible' changes are still 1.6 times more likely in the event of an expansion than in the event of a cutback. Similarly, the four most 'invisible' policy instruments are 1.8 times more likely to be used when pensions are cut than when they are expanded.

Turning to unemployment protection, a very different picture emerges. It is, first of all, worth stressing that the absolute number of expansions is small, 14 in all. The 
majority of them have been in the form of offering more or better training to the jobless. Compared to pensions, it is obvious that British politicians have not shied away from making use of 'visible' policy instruments when retrenching this set of social rights. Nominal benefit cuts make up 21.4 per cent of all cuts and employability requirements another 42.9 per cent. This fits well with the notion that British unemployment protection has seen one of the most substantial roll-backs in modern welfare state history by (mostly Conservative) governments happy to admit their responsibility.

[Table 2-5 about here]

Table 3 presents the Danish data. As in Britain, expansions happen more frequently than cutbacks in the pension area, while cutbacks are more frequent when it comes to unemployment protection. A whopping 79.4 per cent of all pension expansions occur as nominal benefit hikes. This is 4.4 times more often than cutbacks of nominal benefits. Taking age brackets into account, 'visible' policy instruments are still 1.8 times more likely to be used for expansions than cutbacks. The reverse is true for the 'invisible' policy instruments. The assessment base was changed in 21.4 per cent of all cutbacks and never for expansions. Indexation rules were made more generous a single time in the 40 years we study.

Moving to unemployment protection, we see that nominal benefit increases are relatively more frequent than decreases (though there are more cutbacks in absolute numbers). This aligns well with the fact that unemployment protection enjoys a greater degree of public support and protection from elite actors such as unions in Denmark than in Britain (Jensen, 2014). At the same time, employability rules have been used in the context of cutbacks 1.9 times more often than in the context of expansions, which also fits well with what we know from the historical record (ibid.). 'Invisible' policy instruments have been 
employed less frequently than in pensions, probably reflecting that cutbacks to unemployment benefits are easier to justify than to pensions, even in Denmark.

Table 4 presents the data for Germany. Several things are noteworthy compared to the last two tables. First, there have been more cutbacks than expansions in pensions. This also reflects that Germany is the only one of our four countries that has experienced a decline in the Generosity Index (cf. Figure 1). Second, the number of reforms is larger than in both Britain and Denmark. This is a result of the more complex decision-making process in Germany, which leads to a large number of comparably small reforms. Third, there is a more even spread in the chosen policy instruments. This reflects the insurance-based German system where issues relating to contribution levels and periods, qualification periods, and the assessment base of benefits are more central than in the citizenship-based and tax-financed systems of Britain and Denmark.

These distinctions aside, there are also multiple similarities between Germany and the two former countries. The nominal benefits of pensions are 1.9 times more likely to be increased than decreased. Taking age brackets into account, expansions are 1.3 times more likely to happen via a change in these 'visible' policy instruments than are cutbacks. Indexation rules and the assessment base are 1.4 times more likely to be changed when benefits are decreased than when they are increased. Reforms of unemployment protection, meanwhile, exhibit a more balanced use of policy instruments. There are only two areas where we observe marked differences between expansions and cutbacks: employability is more frequently cut and means testing more frequently expanded.

Finally, Table 5 presents the Finnish data. The most noteworthy point here is that unemployment protection has seen more expansions than cutbacks. This is the result of reforms in the 1980s (in particular a large one in 1984) that dramatically improved generosity, something that can also be seen in Figure 2. Before this period, Finland was a 
clear laggard compared to the other Nordic countries. Apart from that difference, Finland resembles the other three countries. Expansions of pensions take the form of changes to nominal benefits 2.4 times more often than decreases, while indexation rules and the assessment base are changed 1.7 times more frequently when cutbacks are on the table. Perhaps because real expansion of unemployment protection has been an option in Finland in the period we study, nominal benefits were 2.1 times more likely to be increased than decreased. As in Germany, means tests were also associated with expansions, while employability, as everywhere, is related to cutbacks.

\section{Formal tests of associations}

Having provided descriptive evidence for the relationship between expansions, retrenchment and the choice of policy instruments, we now briefly report two formal tests of associations to buttress our point that policy-makers are strategic in the choice of policy instruments. To do this, we recoded policy instrument choice in the four countries into an ordinal scale $(1=$ 'clearly invisible', 2 = 'quite invisible', 3 = 'in-between', 4 = 'quite visible', and 5 = 'clearly visible') in line with our argument above. We first calculated Cramer's V-a measure of association for nominal and ordinal scaled variables - to inspect whether there is a systematic association between expanding/retrenching and instrument choice across the two schemes in the four countries.

[Table 6 about here]

Table 6 displays the values of Cramer's $\mathrm{V}$ for the strength of the association between policy direction (expansion vs. retrenchment) and instrument choice (five-point scale). Using Cohen's (1988: 222-225) standards for Cramer's V with four degrees of freedom, the 
association between policy direction and instrument choice for pensions range between medium-strong (for Finland, Germany and Britain) to very strong (for Denmark). For unemployment benefits Cramer's V range between small-to-medium (for Britain and Germany) to medium-strong (Denmark and Finland). This match our descriptive findings above, where we observed stronger patterns for pensions than for unemployment, and provides a statistical evidence of our relatively simple comparison of frequencies in Tables 25 above. $^{4}$

\section{[Table 7 about here]}

To further inspect the strength of the association and to control for bias and outliers, we merged all four country datasets and ran ordinal logit models with policy direction as independent variable and policy instrument choice as dependent variable, again using the five-point-scale. Since the purpose is to test the robustness of our conclusions, we ran the analysis with so-called jackknife estimated standard errors to control for bias and potential outliers in our policy data. Table 7 reports a total of four models (M1-M4). M1 provides the baseline result, showing that the direction of a reform is strongly correlated with the degree of visibility. In M2 we include a dummy for each country to control for country-specific factors. We use Denmark as reference category because Table 3 above suggests that Denmark has seen the most extensive use of visible instruments given its overall reform activity. It turns out that this impression is borne out of the more formal test as well with Germany coming out as the country with relatively fewest visible instruments. M3 and M4 look at the two domains

\footnotetext{
${ }^{4}$ The values for Cramer's V are robust to changes in our visibility coding: When two out of our 13 instruments are randomly put in neighboring visibility categories instead of the original ones, values for Cramer's V do not change substantially and even increase in some cases.
} 
of pensions and unemployment protection, respectively. ${ }^{5}$ It is evident that the correlation between reform direction and degree of visibility is much stronger for the former than for the latter, confirming our expectation that policy-makers act more strategic on the more popular pension scheme. ${ }^{6}$

All in all, Table 7 allow us to conclude that (1) the direction of reforms matters for use of visibility (arguably due to politicians' desire to avoid blame for unpopular decisions); (2) much more so for pensions than for unemployment protection (arguably due to differences in deservingness) and (3) 'invisible' reforms are used more often in Denmark than in Germany (presumably due to differences in government clarity). Interestingly enough, Britain and Finland comes in between the two extremes of Denmark and Germany, so it is obvious that all cross-country differences cannot be boiled-down to a question of how easy it is to ascribed blame to the government (at least not the way we have conceptualized it here).

\section{Conclusion}

There is little doubt that the data reported here broadly supports the new politics perspective. 'Visible' policy instruments, above all else nominal benefits, were much more likely to be used for expansionary purposes than for retrenchment - and especially so for the highly popular old-age pensions. 'Invisible' policy instruments such as indexation rules and rules governing the assessment base of benefits were more likely to be employed for cutbacks than for expansions, and again most markedly in the domain of pensions. Choice of policy instruments, of course, also reflects the institutional design of the welfare state, so it is not surprising that there were cross-country differences as well. In the insurance-based systems

\footnotetext{
${ }^{5}$ One reform falls into both domains, which means that we lose one observation when analyzing the data separately for pensions and unemployment.

${ }^{6} \mathrm{We}$ have also tested if the marginal effect of direction on degree of visibility is significant in all four countries, which it is.
} 
of Germany and Finland, a broader selection of policy instruments is used than in the citizenship-based systems of Britain and Denmark.

One of the most damaging critiques of the new politics perspective has been that governments appear to be able to get away with retrenchment without an electoral backlash (Giger, 2010; 2011; Giger and Nelson, 2011; Schumacher et al., 2013). One reason for this is probably that Pierson's original thinking about voters is too blunt. Voters care not only about a big welfare state, but also about a sound economy, and there are variation both between voters and over time how salient each of these concerns are (Arndt, 2013; Giger and Nelson, 2013). Still, our findings point to an additional explanation that relates directly back to Pierson's original argument: governments escape punishment because they expertly select the policy instruments that maximize credit for expansions and minimize blame for cutbacks. In fact, our findings clearly emphasize the strategic room for manoeuvre that governments enjoy when they reform the welfare state. By strategically using invisible instruments for cutbacks and visible instruments for expansions, welfare state change may indeed be possible without major electoral slack. Hence, governments do not get away with retrenchment without backlash because voters do not care, but because governments employ reform strategies.

Future research will need to test this straightforward expectation that the effect of welfare cutbacks on governments' vote share is conditional upon the policy instruments chosen to implement the reform. In doing so, it will be important to remember that it may not necessarily be the case that policy instruments are equally 'visible' or 'invisible' in different countries. To be sure, nominal benefits are universally easier to understand than indexation rules and assessment base. Yet the latter, more technical policy instruments may nonetheless play a large role for voters in insurance-based systems for the simple reason that they are so 
important for the generosity of benefits in these systems. Whether or not that is the case will be a topic for future research. 


\section{References}

Allan JP and Scruggs L (2004) Political partisanship and welfare state reform in advanced industrial societies. American Journal of Political Science 48(3): 496-512.

Arndt C (2013) The Electoral Consequences of Third Way Welfare State Reforms: Social Democracy's Transformation and its Political Costs. Amsterdam: Amsterdam University Press.

Arnold RD (1990) The Logic of Congressional Action. New Haven and London: Yale University Press.

Castles F and Obinger H (2008) Worlds, Families, Regimes: Country Clusters in European and OECD Area Public Policy. West European Politics 31(1-2): 321-344.

Clasen J (2007) Reforming European Welfare States: Germany and the United Kingdom Compared. Oxford and New York: Oxford University Press.

Clasen J and Clegg D (2011) Regulating the Risk of Unemployment: National Adaptations to Post-Industrial Labour Markets in Europe. Oxford and New York: Oxford University Press.

Clayton R and Pontusson J (1998) Welfare-state retrenchment revisited: Entitlement cuts, public sector restructuring, and inegalitarian trends in advanced capitalist societies. World Politics 51(01): 67-98.

Cohen, J (1988) Statistical Power Analysis for the Behavioral Sciences (2nd ed.), Hillsdale, New Jersey: Lawrence Erlbaum Associates, Inc.

Esping-Andersen G (1990) The Three Worlds of Welfare Capitalism. Princeton, New Jersey: Princeton University Press.

Giger N (2010) Do voters punish the government for welfare state retrenchment? A comparative of electoral costs associated with social policy. Comparative European Politics 8(4): 415-443.

Giger N (2011) The Risk of Social Policy? The Electoral Consequences of Welfare State Retrenchment and Social Policy Performance in OECD Countries. London and New York: Routledge.

Giger N and Nelson M (2011) The electoral consequences of welfare state retrenchment: Blame avoidance or credit claiming in the era of permanent austerity? European Journal of Political Research 50(1): 1-23. 
Giger N and Nelson M (2013) The welfare state or the economy? Preferences, constituencies, and strategies for retrenchment. European Sociological Review 29(5): 1083-1094.

Green-Pedersen C, Christiansen FJ, Euchner EM, Jensen C, Turnpenny J (2012) Dismantling by default? The indexation of social benefits in four countries. In: Bauer MW, Jordan A, Green-Pedersen C, Héritier A (eds) Dismantling Public Policies: Preferences, Strategies, and Effects. Oxford: Oxford University Press, pp. 129-151.

Hobolt, S, Tilley J and Banducci, S (2013). Clarity of responsibility: How government cohesion conditions performance voting, European Journal of Political Research, 52:2, 164-187.

Jensen C (2011) Marketization via compensation: Health care and the politics of the right in advanced industrialized nations. British Journal of Political Science 41(04): 907-926.

Jensen, C (2012). Labour-market- vs. life-course-related social policies: understanding crossprogramme differences, Journal of European Public Policy, 19:2, 275-291.

Jensen C (2014) The Right and the Welfare State. New York and Oxford: Oxford University Press.

Jensen C and Petersen MB (2016) The deservingness heuristic and the politics of health care. American Journal of Political Science. Forthcoming.

Kangas O (2007) Finland: Labor markets against politics. In: Immergut E et al. (eds) The Handbook of West European Pension Politics. Oxford: Oxford University Press, pp. 248-296.

Kangas O and Saari J (2007) Finland: Towards more proactive policy. In: Kvist J and Saari J (eds) The Europanisation of Social Protection. Bristol: Policy Press, pp. 153-173.

Korpi W and Palme J (1998) The paradox of redistribution and strategies of equality: Welfare state institutions, inequality, and poverty in the Western countries. American Sociological Review 63(5): 661-687.

Korpi W and Palme J (2003) New politics and class politics in the context of austerity and globalization: Welfare state regress in 18 countries, 1975-95. American Political Science Review 97(03): 425-446.

Lijphart A (1999) Patterns of Democracy: Government Forms and Performance in Thirty-Six Democracies. New Haven: Yale University Press.

Lindbom A (2001) Dismantling the Social Democratic welfare model? Has the Swedish welfare state lost its defining characteristics? Scandinavian Political Studies 24(3): 171-193. 
Lindbom A (2007) Obfuscating retrenchment: Swedish welfare policy in the 1990s. Journal of Public Policy 27(02): 129-150.

Pierson P (1993) When effect becomes cause: Policy feedback and political change. World Politics 45(04): 595-628.

Pierson P (1994) Dismantling the Welfare State? Reagan, Thatcher, and the Politics of Retrenchment. Cambridge: Cambridge University Press.

Pierson P (1996) The new politics of the welfare state. World Politics 48(2): 143-179.

Powell Jr, GB and Whitten GD (1993) A cross-national analysis of economic voting: Taking account of the political context. American Journal of Political Science: 391-414.

Schumacher G, Vis B and van Kersbergen K (2013) Political parties' welfare image, electoral punishment and welfare state retrenchment. Comparative European Politics 11(1): 121.

Scruggs L (2014) Social Welfare Generosity Scores in CWED 2: A Methodological Genealogy. Working paper.

Scruggs L and Allan J (2006) Welfare-state decommodification in 18 OECD countries: A replication and revision. Journal of European Social Policy 16(1): 55-72.

Scruggs L, Detlef J and Kuitto K. (2014) Comparative Welfare Entitlements Dataset 2: Version 2014-03. University of Connecticut and University of Greifswald.

Van Oorschot W (2006) Making the difference in social Europe: Deservingness perceptions among citizens of European welfare states. Journal of European Social Policy 16(1): $23-42$.

Weaver RK (1986) The politics of blame avoidance. Journal of Public Policy 6(4): 371-398.

Wenzelburger G (2011) Political strategies and fiscal retrenchment: Evidence from four countries. West European Politics 34(6): 1151-1184.

Wolf, F, Zohlnhöfer, R and Wenzelburger, G (2014). The Politics of Public and Private Pension Generosity in Advanced Democracies, Social Policy \& Administration, 48:1, 86-106.

Zohlnhöfer R (2007) The politics of budget consolidation in Britain and Germany: The impact of blame avoidance opportunities. West European Politics 30(5): 1120-1138. 
Figure 1. Generosity Index for old-age pensions 1974-2010

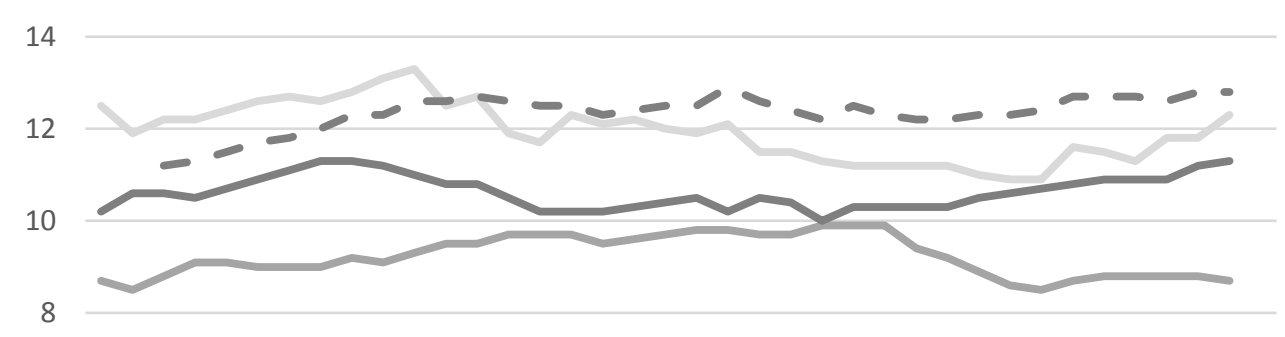

6

4

2

0

$\begin{array}{llllllllll}1974 & 1978 & 1982 & 1986 & 1990 & 1994 & 1998 & 2002 & 2006 & 2010 \\ & & & & & & & & & \end{array}$

Source: Scruggs et al. (2014). 
Figure 2. Generosity Index for unemployment benefits 1974-2010/11

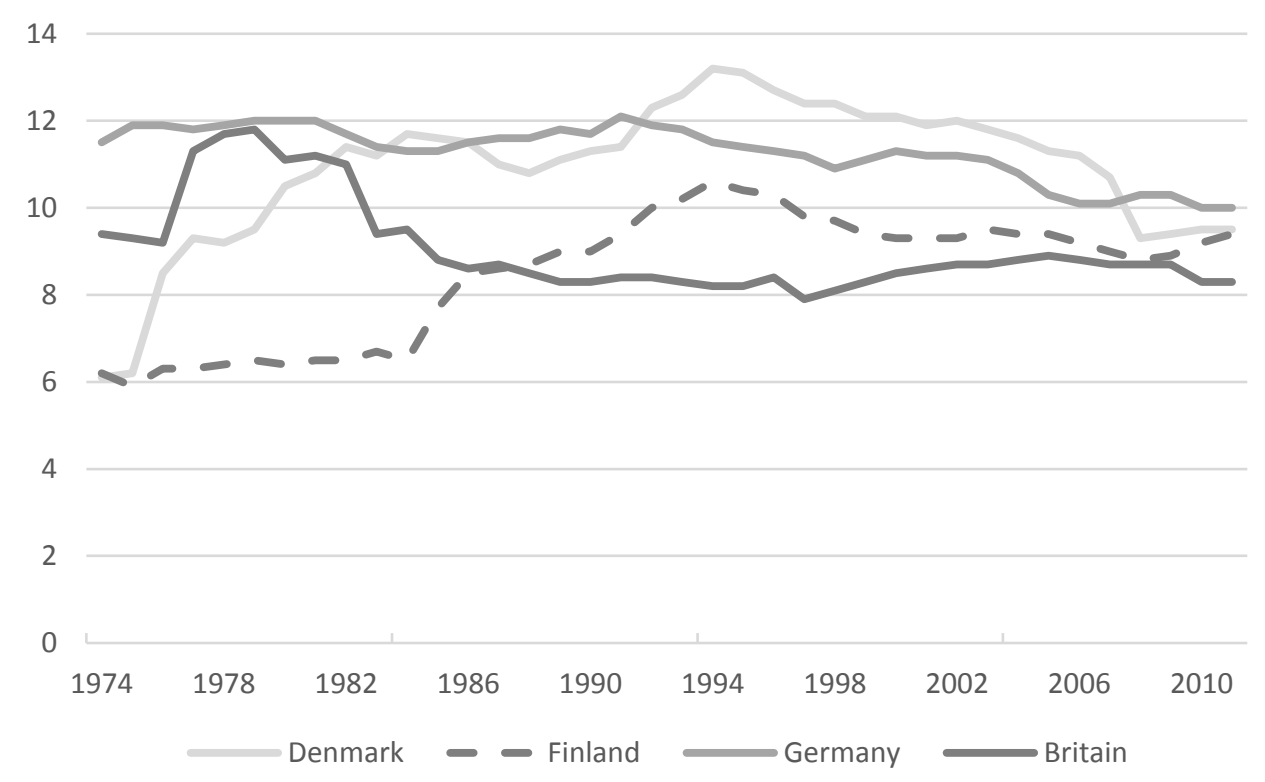

Source: Scruggs et al. (2014). 
Table 1. Policy instruments coded

\begin{tabular}{|c|c|c|c|}
\hline Dimension & No. & Policy instrument & Description \\
\hline \multirow[t]{6}{*}{ Rules of access } & 1 & Qualification period & $\begin{array}{l}\text { How long does it take for a person to } \\
\text { become eligible? }\end{array}$ \\
\hline & 2 & Contribution period & $\begin{array}{l}\text { How long must a person contribute to a } \\
\text { scheme before becoming eligible? }\end{array}$ \\
\hline & 3 & Contribution level & How much must a person contribute? \\
\hline & 4 & Waiting period & $\begin{array}{l}\text { How long after a social risk occurs } \\
\text { before a person is eligible? }\end{array}$ \\
\hline & 5 & Age brackets & $\begin{array}{l}\text { How old must a person be to be } \\
\text { eligible? }\end{array}$ \\
\hline & 6 & Means test & Is there a means test? \\
\hline \multirow[t]{4}{*}{ Rules of benefits } & 7 & Duration period & $\begin{array}{l}\text { How long can a recipient receive } \\
\text { benefits? }\end{array}$ \\
\hline & 8 & Nominal value & $\begin{array}{l}\text { What is the nominal value of the } \\
\text { benefits? }\end{array}$ \\
\hline & 9 & Indexation rule & $\begin{array}{l}\text { Is the nominal benefit automatically } \\
\text { regulated and with what factor? }\end{array}$ \\
\hline & 10 & Assessment base & $\begin{array}{l}\text { Has the base for calculating benefits } \\
\text { changed? }\end{array}$ \\
\hline \multirow[t]{3}{*}{ Rules of conduct } & 11 & Employability & $\begin{array}{l}\text { Is the recipient required to or offered } \\
\text { the opportunity to voluntarily } \\
\text { participate in activities meant to } \\
\text { increase the likelihood of getting a job? }\end{array}$ \\
\hline & 12 & Health documentation & $\begin{array}{l}\text { Is the recipient required to document } \\
\text { that she is unable to work? }\end{array}$ \\
\hline & 13 & Residence & $\begin{array}{l}\text { Does it matter where and under what } \\
\text { circumstances the recipient lives? }\end{array}$ \\
\hline
\end{tabular}


Figure 3. Reform events in unemployment protection in Britain 1974-2014

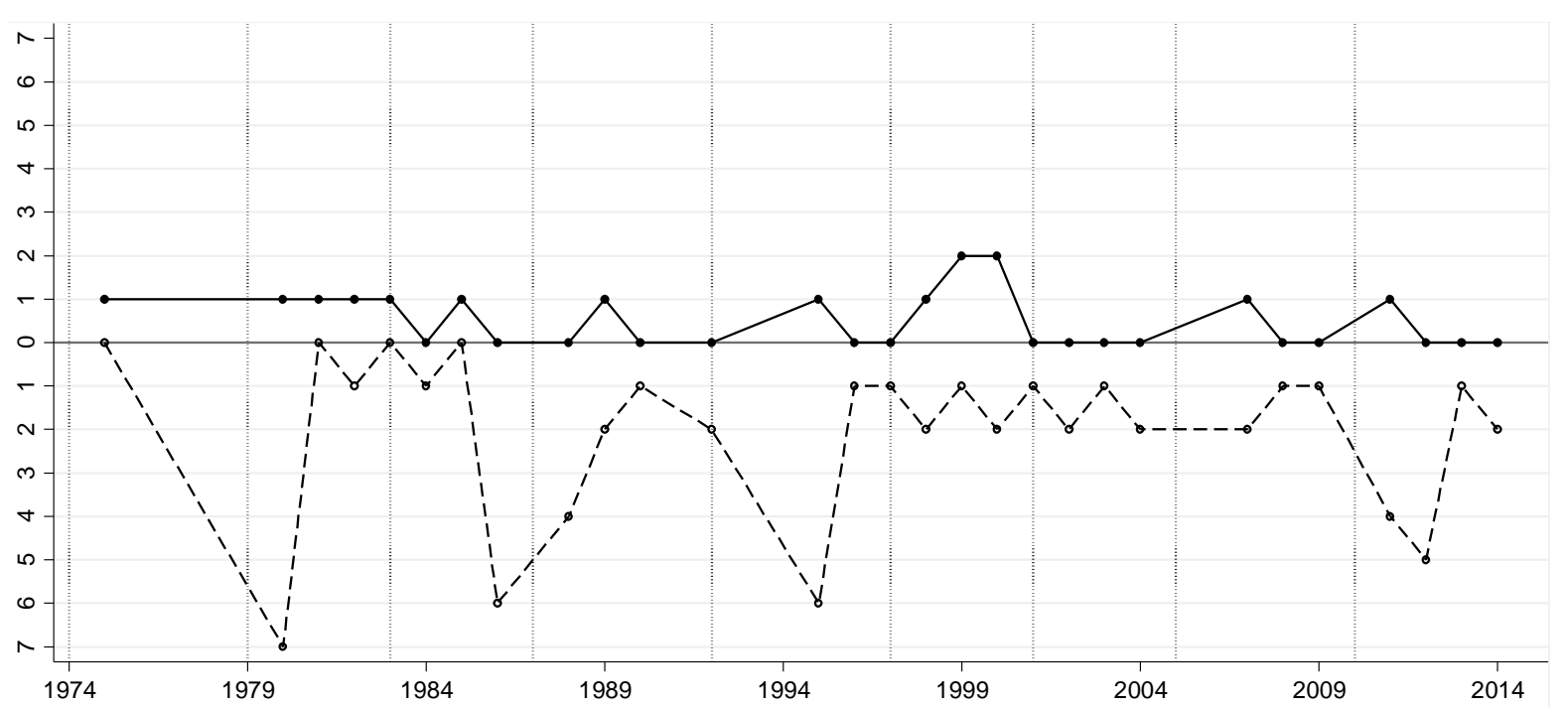

Note: The black circles with the full line connecting them represent expansionist reform events. The hollow circles with the dashed line represent reductions. The number of reform events is reported on the vertical axis. The thin vertical dashed lines (e.g., in 1979, 1983, and 1987) represent election years. 
Table 2. Instrument choice in Britain 1974-2014

\begin{tabular}{|c|c|c|c|c|c|}
\hline & & \multicolumn{2}{|c|}{ Pensions } & \multicolumn{2}{|c|}{ Unemployment } \\
\hline & & Expansions & Cutbacks & Expansions & Cutbacks \\
\hline \multirow{5}{*}{ 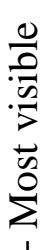 } & Nominal benefit level & 54.8 & 17.2 & 7.1 & 21.4 \\
\hline & Age brackets & 0.0 & 17.2 & 7.1 & 3.6 \\
\hline & Duration period & 2.4 & 0.0 & 0.0 & 3.6 \\
\hline & Employability & 0.0 & 0.0 & 57.1 & 42.9 \\
\hline & Means test & 2.4 & 3.5 & 0.0 & 1.8 \\
\hline \multirow{10}{*}{ 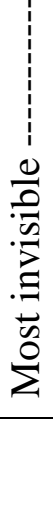 } & Waiting period & 0.0 & 3.5 & 0.0 & 3.6 \\
\hline & Contribution level & 16.7 & 20.7 & 7.1 & 3.6 \\
\hline & Residence & 0.0 & 0.0 & 0.0 & 3.6 \\
\hline & Health documentation & 0.0 & 3.5 & 0.0 & 1.8 \\
\hline & Contribution period & 4.7 & 6.9 & 0.0 & 0.0 \\
\hline & Qualification period & 0.0 & 3.5 & 14.3 & 5.4 \\
\hline & Indexation rules & 9.5 & 13.8 & 7.1 & 8.9 \\
\hline & Assessment base & 9.5 & 10.3 & 0.0 & 0.0 \\
\hline & Number of observations & 42 & 29 & 14 & 56 \\
\hline & Expansions/cutbacks & \multicolumn{2}{|c|}{1.5} & \multicolumn{2}{|c|}{0.25} \\
\hline
\end{tabular}

Note: The numbers reported are within-column percentages except the bottom two rows, which report the number of observations and the ratio between expansions and cutbacks, respectively. The instruments are ranked with most 'visible' at the top and most 'invisible' at the bottom. 
Table 3. Instrument choice in Denmark 1974-2014

\begin{tabular}{|c|c|c|c|c|c|}
\hline & & \multicolumn{2}{|c|}{ Pensions } & \multicolumn{2}{|c|}{ Unemployment } \\
\hline & & Expansions & Cutbacks & Expansions & Cutbacks \\
\hline \multirow{5}{*}{$\begin{array}{l}\frac{0}{0} \\
\frac{\pi}{2} \\
\frac{0}{2} \\
\frac{0}{2}\end{array}$} & Nominal benefit level & 79.4 & 17.9 & 50.0 & 27.4 \\
\hline & Age brackets & 2.9 & 28.6 & 7.1 & 7.1 \\
\hline & Duration period & 1.5 & 3.6 & 4.8 & 8.3 \\
\hline & Employability & 1.5 & 0.0 & 16.7 & 32.1 \\
\hline & Means test & 0.0 & 7.1 & 0.0 & 3.6 \\
\hline \multirow{10}{*}{ 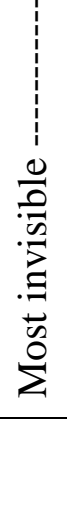 } & Waiting period & 0.0 & 0.0 & 2.4 & 2.4 \\
\hline & Contribution level & 5.9 & 14.3 & 4.8 & 7.1 \\
\hline & Residence & 4.4 & 3.6 & 4.8 & 1.2 \\
\hline & Health documentation & 0.0 & 0.0 & 0.0 & 0.0 \\
\hline & Contribution period & 2.9 & 3.6 & 4.8 & 9.5 \\
\hline & Qualification period & 0.0 & 0.0 & 0.0 & 0.0 \\
\hline & Indexation rules & 1.5 & 0.0 & 2.4 & 1.2 \\
\hline & Assessment base & 0.0 & 21.4 & 2.4 & 0.0 \\
\hline & Number of observations & 68 & 28 & 42 & 84 \\
\hline & Expansions/cutbacks & \multicolumn{2}{|c|}{2.4} & \multicolumn{2}{|c|}{0.5} \\
\hline
\end{tabular}

Note: See Table 1. 
Table 4. Instrument choice in Germany 1974-2014

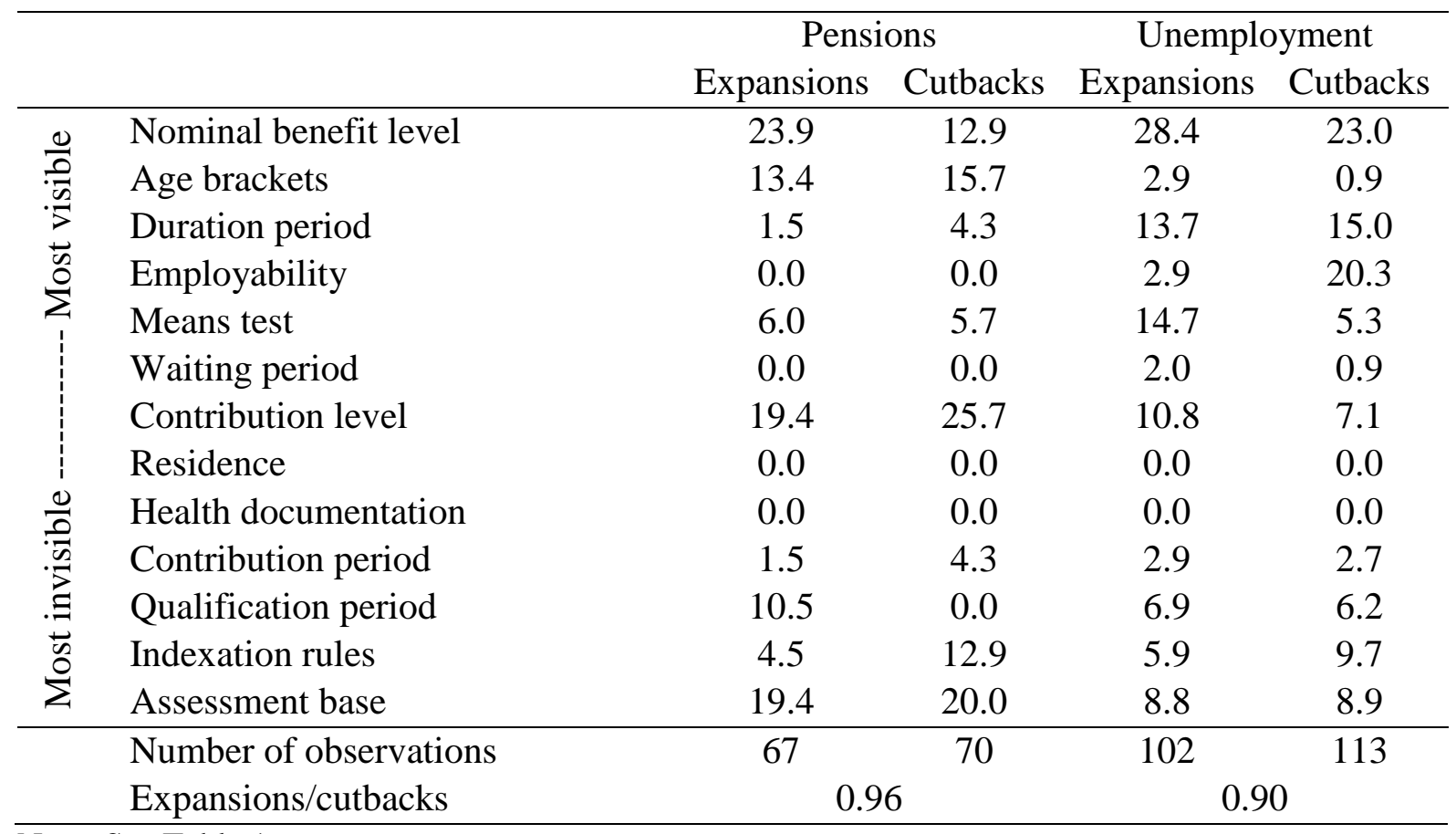

Note: See Table 1. 
Table 5. Instrument choice in Finland 1974-2014

\begin{tabular}{|c|c|c|c|c|c|}
\hline & & \multicolumn{2}{|c|}{ Pensions } & \multicolumn{2}{|c|}{ Unemployment } \\
\hline & & Expansions & Cutbacks & Expansions & Cutbacks \\
\hline \multirow{5}{*}{$\begin{array}{l}\frac{0}{0} \\
\frac{\sqrt[\pi]{2}}{2} \\
\frac{\tilde{n}}{0} \\
\sum^{2}\end{array}$} & Nominal benefit level & 34.4 & 14.3 & 35.3 & 16.9 \\
\hline & Age brackets & 14.1 & 22.5 & 0.0 & 7.7 \\
\hline & Duration period & 0.0 & 0.0 & 8.1 & 9.2 \\
\hline & Employability & 3.1 & 4.1 & 14.7 & 43.1 \\
\hline & Means test & 21.9 & 8.2 & 25.0 & 4.6 \\
\hline \multirow{10}{*}{ 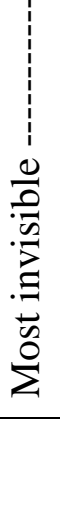 } & Waiting period & 0.0 & 0.0 & 2.2 & 7.7 \\
\hline & Contribution level & 1.6 & 0.0 & 0.0 & 0.0 \\
\hline & Residence & 1.6 & 0.0 & 0.7 & 3.1 \\
\hline & Health documentation & 0.0 & 6.1 & 0.0 & 0.0 \\
\hline & Contribution period & 1.6 & 0.0 & 5.9 & 1.5 \\
\hline & Qualification period & 3.1 & 2.0 & 6.6 & 3.1 \\
\hline & Indexation rules & 6.3 & 14.3 & 0.7 & 3.1 \\
\hline & Assessment base & 12.5 & 18.4 & 0.7 & 0.0 \\
\hline & Number of observations & 64 & 49 & 136 & 65 \\
\hline & Expansions/cutbacks & \multicolumn{2}{|c|}{1.3} & \multicolumn{2}{|c|}{2.1} \\
\hline
\end{tabular}

Note: See Table 1. 
Table 6: Cramer's V for association between policy direction and instrument choice across policydomains in four countries, 1974-2014

\begin{tabular}{lcccc}
\hline & Denmark & Finland & Germany & UK \\
\hline Pensions & 0.429 & 0.277 & 0.218 & 0.223 \\
Unemployment & 0.277 & 0.248 & 0.138 & 0.182 \\
\hline Number of obs. & 222 & 314 & 352 & 141 \\
\hline
\end{tabular}

Degrees of freedom for Cramer's $V=4$. 
Table 7: Ordinal logit model of effect of reform direction on visibility of policy changes

\begin{tabular}{|c|c|c|c|c|}
\hline & $\begin{array}{l}\text { M1 } \\
\text { All }\end{array}$ & $\begin{array}{l}\text { M2 } \\
\text { All }\end{array}$ & $\begin{array}{c}\text { M3 } \\
\text { Pensions }\end{array}$ & $\begin{array}{c}\text { M4 } \\
\text { Unemployment }\end{array}$ \\
\hline \multirow{2}{*}{ Reform direction (dummy) } & $0.522 * * *$ & $0.525 * * *$ & $0.684 * * *$ & $0.294 !$ \\
\hline & $(0.114)$ & $(0.119)$ & $(0.195)$ & $(0.162)$ \\
\hline \multirow[t]{2}{*}{ Germany } & & $-1.178 * * *$ & $-1.437 * * *$ & $-0.896 * * *$ \\
\hline & & $(0.166)$ & $(0.278)$ & $(0.229)$ \\
\hline \multirow[t]{2}{*}{ Finland } & & $-0.692 * * *$ & $-1.041 * * *$ & -0.347 \\
\hline & & $(0.161)$ & $(0.291)$ & $(0.214)$ \\
\hline \multirow[t]{2}{*}{ Britain } & & $-0.805^{* * *}$ & $-1.043 * *$ & $-0.622 *$ \\
\hline & & $(0.203)$ & $(0.321)$ & $(0.261)$ \\
\hline \multirow[t]{2}{*}{ Cut point 1} & $-1.595 * * *$ & $-2.373 * * *$ & $-1.932 * * *$ & $-2.821 * * *$ \\
\hline & $(0.105)$ & $(0.154)$ & $(0.284)$ & $(0.209)$ \\
\hline \multirow[t]{2}{*}{ Cut point 2} & $-1.067 * * *$ & $-1.831 * * *$ & $-1.629 * * *$ & $-1.960 * * *$ \\
\hline & $(0.0899)$ & $(0.147)$ & $(0.279)$ & $(0.190)$ \\
\hline \multirow[t]{2}{*}{ Cut point 3} & $-0.452 * * *$ & $-1.198 * * *$ & $-0.855^{* *}$ & $-1.416 * * *$ \\
\hline & $(0.0825)$ & $(0.144)$ & $(0.277)$ & $(0.187)$ \\
\hline \multirow[t]{2}{*}{ Cut point 4} & $0.776^{* * *}$ & 0.0768 & -0.435 & $0.465^{* *}$ \\
\hline & $(0.0847)$ & $(0.138)$ & $(0.273)$ & $(0.177)$ \\
\hline $\mathrm{N}$ & 1,030 & 1,030 & 416 & 613 \\
\hline -2 loglikelihood & -1480 & -1453 & -539.7 & -824.2 \\
\hline Degrees of freedom & 1 & 4 & 4 & 4 \\
\hline $\operatorname{LR} \chi^{2}$ & $21.24 * * *$ & $75.60 * * *$ & $50.31 * * *$ & $23.47 * * *$ \\
\hline $\mathrm{BIC}^{\prime}$ & -14.30 & -47.85 & -26.19 & 2.20 \\
\hline
\end{tabular}

Note: Jackknifed standard errors in parentheses, $* * * \mathrm{p}<0.001, * * \mathrm{p}<0.01, * \mathrm{p}<0.05$, ! $\mathrm{p}<0.10$; the dependent variable is visibility of policy changes (ordinal scale: 1 'clearly invisible', 2 'quite invisible', 3 'in-between', 4 'quite visible', 5 'clearly visible'). 